\title{
Thermal structure and circulation in Lake Chapala, Mexico
}

\author{
David AVALOS-CUEVA, ${ }^{1,2}$ Anatoliy FILONOV, ${ }^{3}$ Iryna TERESHCHENKO,${ }^{3}$ César O. MONZÓN, ${ }^{3}$ \\ Federico Á. VELÁZQUEZ-MUÑOZ ${ }^{3}$
}

${ }^{1}$ Posgrado de Ciencias del Mar y Limnología, Universidad Nacional Autónoma de México, Ciudad Universitaria, 70-305, 04510 México DF; ${ }^{2}$ Instituto Tecnológico Superior de Arandas, Apdo. Postal 4-7180, Arandas, Jalisco; ${ }^{3}$ Department of Physics, University of Guadalajara, Apdo. Postal 4-4040, Guadalajara 44421, Jalisco, México.

*Corresponding author: david_avalos_cueva@hotmail.com

\begin{abstract}
This study analyzed and discussed the instrumental measurements of temperature and currents made on January 10, 2007, in Lake Chapala. We received new data on the formation of the thermocline. It is shown that the thermocline of the lake is formed only in the daytime and in a top-heated 0.5-1.0 m layer. The vertical temperature gradient reaches $2.5^{\circ} \mathrm{C}$ in the first meter, and the spatial average temperature across the lake showed that the northern end of the lake is, on average, $1^{\circ} \mathrm{C}$ warmer than the southern end. We numerically modeled the currents in the lake for the dry season using the HAMSOM 2D hydrodynamic model. The simulation results are in good agreement with the acoustic Doppler current profiler ADCP measurements. In the dry season, two gyres were found: a cyclonic gyre in the eastern part and an anticyclonic gyre in the western part.
\end{abstract}

Key words: Lake Chapal; HAMSOM model; current pattern; temperature variability; water column stratification.

Received: January 2015. Accepted: December 2015.

\section{INTRODUCTION}

Lake Chapala is the largest natural lake in Mexico. It is located along the Trans-Mexican volcanic belt, south of the metropolitan zone of Guadalajara, Jalisco $\left(20^{\circ} 15^{\prime} \mathrm{N}\right.$ and $103^{\circ} 05^{\prime} \mathrm{W}$ ) and at an altitude of $1524 \mathrm{~m}$ asl (Fig. 1). Its dimensions are 68 by $18 \mathrm{~km}$. Its depth is an average of $6 \mathrm{~m}$, with a maximum near $11 \mathrm{~m}$. The lake's tributary and effluent systems are the Lerma and Santiago Rivers. Meteorological and hydrological balance data reported by the National Water Commission of Mexico (CNA) show that the average annual precipitation is $750 \mathrm{~mm}$ and that evaporation ranges from 1000 to $1400 \mathrm{~mm}$ per year, resulting in a negative water balance. The deficiency is compensated by the input of water from the Lerma River and the water runoff from its basin (Mosiño and García, 1974; Jáuregui, 1995; Filonov and Tereshchenko, 1997). In dry years, the annual precipitation drops to $500 \mathrm{~mm}$, and the lake does not contribute water to the Santiago River (Riehl, 1979). However, in years with more rainfall, the annual precipitation can reach up to $1000 \mathrm{~mm}$ and can generate an important volume of water exiting through the river.

Lake Chapala shows marked diurnal temperature variations and a thermocline forms during the diurnal period, which can produce more extreme temperature differences than occur due to seasonal variations. This is a feature of shallow tropical lakes, such as Lake George in Uganda (Ganf and Viner, 1973), Lake Opi in Nigeria (Hare and Carter, 1984) and Lake Kasumigaura in Japan (Ishikawa and Tanaka, 2010).
Currently, the only studies on the dynamics and the thermal structure of the lake come from fairly simple samplings and meteorological data used in primitive equation models, which result from averaging data over short periods of time; some results are empirical (Hansen, 1994; Filonov and Tereshchenko, 1999a, 1999b; Avalos, 2003; De-Anda, 2004). Therefore, the dynamics and the thermal structure in the lake remain poorly known.

The present study's objective is to reveal a new image of Lake Chapala's hydrodynamics in the dry season using the semi-implicit model HAMSOM (Hamburg Shelf Ocean Model), implemented with the wind field obtained from the network of seven weather stations distributed around and in the center of the lake. Subsequently, we compared the model results with measurements of crosssections performed with an ADCP (Acoustic Doppler Current Profile) during the dry season (10 January 2007).

\section{METHODS}

\section{Field measurements}

The information was obtained from an experiment conducted at Lake Chapala on 10 January 2007. The experiment consisted of towing a 7.8-m-long thermistor chain, with a hydrodynamic shape and an Acoustic Doppler Current Profiler (ADCP) RD $600 \mathrm{kHz}$ Instrument. Fig. 1b shows the sampling diagram. The chain contained 14 thermistors (12 HOBO Pro v2, one HOBOLEVEL sensor and one SBE-39) that were evenly distrib- 
uted from below the water surface to a depth of $7.2 \mathrm{~m}$. The chain was towed from the boat. As a base for the sensors, we used a metallic angular pattern in which the thermistors were fixed. At the moment of crossing the fishing nets, the chain drops down and gradually deepening it without causing any damage. Pressure sensors from the HOBO-LEVEL and SBE-39 loggers controlled the depth of the chain. Special deadweight anchors were used for the deep penetration of the chains. The sampling interval of the temperature and pressure sensors was $60 \mathrm{~s}$.

The ADCP was assembled with its transducers upside down on a frame attached to the boat's starboard, which was towed at a constant velocity of $1.39 \mathrm{~m} \mathrm{~s}^{-1}$. It was configured in the bottom-track mode and programmed with 15$\mathrm{s}$ intervals and 13 cells that were $50 \mathrm{~cm}$ thick. The methodology consisted of passing through the predetermined area shown in the sampling diagram (Fig. 1a), towing the thermistor chain and the ADCP, and simultaneously recording the geographic position with a Garmin GPS 12.

The ADCP data were calibrated according to Trump and Marmorino (1997), and bad data were removed following the procedure explained by Valle-Levinson and Atkinson (1999). Then, a correction by navigation direc-

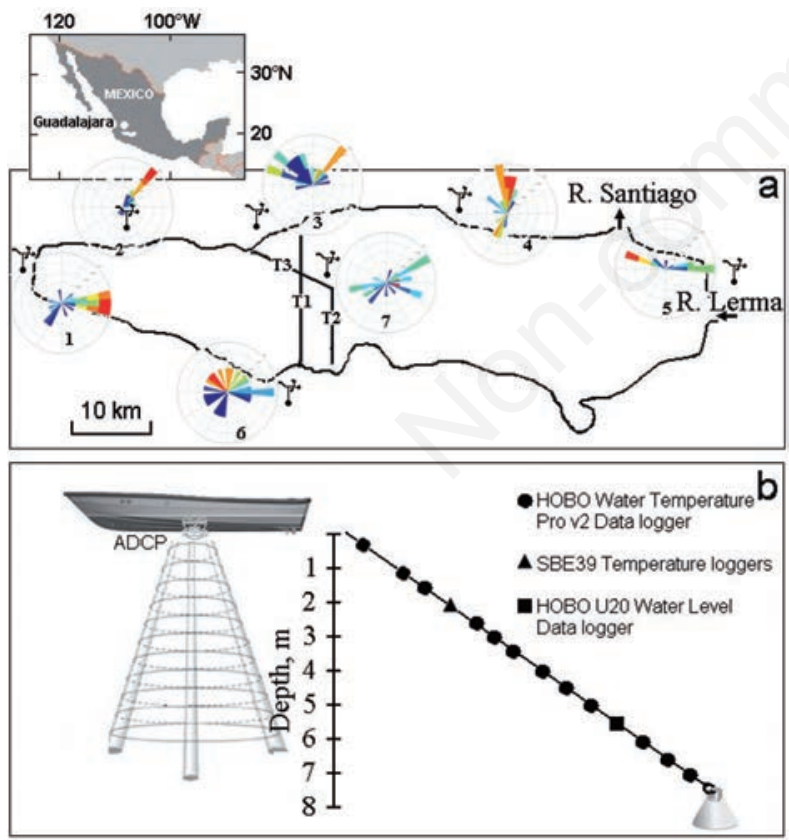

Fig. 1. a) Map of Lake Chapala. The solid lines T1, T2 and T3 represent the general diagram of the experiment done on 10 January 2007. The weather vane represents the distribution and average frequency of the wind direction from the network of the weather stations for the dry season in the years 2006 and 2007; 1, Jocotepec; 2, Atequiza; 3, Chapala; 4, Poncitlán; 5, Jamay; 6, Tizapán; 7, Alacranes Island. b) Distribution of the thermistor chains and the ADCP set-up on the boat. tion was applied. The temperature records from the water columns obtained from the thermistor chain were adjusted by depth through interpolation with a natural cubic spline with the not-a-knot condition (Jain, 2003).

\section{HAMSOM semi-implicit model}

The model used to conduct our calculation is a variant of the average-vertical HAMSOM model and is bi-dimensional, non-linear, and semi-implicit. This model was used to shape both the fluctuations from the barotropic level and the horizontal currents resulting from the circulation from the wind above the lake. The model is written in a finite difference scheme, using the Arakawa-C grid (Arakawa and Lamb, 1977). This represents the simultaneous solution to the Navier-Stokes equation and the equation of continuity in the following manner:

$$
\begin{aligned}
& \frac{\partial U}{\partial t}+\frac{U}{(H+\zeta)} \frac{\partial U}{\partial x}+\frac{V}{(H+\zeta)} \frac{\partial U}{\partial y}-f V=-g(H+\zeta) \frac{\partial \zeta}{\partial x}+A_{H} \nabla_{h}^{2} U+\tau_{s}-\tau_{b} \text { (eq. 1) } \\
& \frac{\partial V}{\partial t}+\frac{U}{(H+\zeta)} \frac{\partial V}{\partial x}+\frac{V}{(H+\zeta)} \frac{\partial V}{\partial y}+f U=-g(H+\zeta) \frac{\partial \zeta}{\partial y}+A_{H} \nabla_{h}^{2} V+\tau_{s}-\tau_{b}, \text { (eq. 2) } \\
& \frac{\partial \zeta}{\partial t}+\frac{\partial U}{\partial x}+\frac{\partial V}{\partial y}=0
\end{aligned}
$$

Here, $U$ and $V$ correspond to the zonal and meridional current velocities, respectively, $\zeta$ is the water level elevation, $t$ is the time, $H$ is the lake depth, $g$ is the acceleration due to gravity, $\tau_{s}^{(x)(y)}=\lambda_{w}\left(W^{(x)}, W^{(y)}\right) \sqrt{W^{(x) 2}+W^{(y) 2}}$ is the wind stress, $\lambda_{W}=3.2 \times 10^{-3}$ is the proportionality constant, $\left(W^{(x)}, W^{(y)}\right)$ are the components of wind velocity, $r_{b}^{(x)(y)}=\frac{r(u, v)}{(H+\zeta)} \sqrt{U^{2}+V^{2}}$ is the bottom stress friction, $r(u, v)=1.5 \times 10^{-3}$, is $f$ the Coriolis parameter, $A_{H}=A_{k} \Delta L H$ is the horizontal eddy viscosity coefficient, $A_{k}=5 \times 10^{-3}$ is a proportionality constant and $\Delta L$ is the step length scale. The model has been previously used in the Gulf of California, Carbajal (1993); Marinone (2003); in the Santa Maria del Oro Volcanic Lake, Serrano et al., (2002); and in the North Sea, Hainbucher et al., (1987) and Ilyina et al., (2006).

To study the circulation patterns throughout the dry period, a simulation was conducted with the HAMSOM model forced by the wind-field obtained from the network weather stations. The bathymetric grid had a $97 \times 270$ mesh: $\Delta x=\Delta y=300 \mathrm{~m}$ and $\Delta t=30 \mathrm{~s}$. The simulations started from a condition of no movement and were run for 30 days before obtaining a stable initial condition.

\section{RESULTS}

\section{Wind}

The average wind value from 10 December 2006 to 10 January 2007 is given as the daily course of wind velocity (for each hour of the day in climatic stations Chapala, Island Alacranes and Tizapan, shown in Fig. 2 a,d). 
Clearly, the wind had a lake breeze character, as shown in the weathervanes of the meteorological stations distributed on the lake and as presented in Fig. 1a.

On the night of 10 January 2007, the wind magnitude was weak and had a direction toward the lake. The maximum value of night breeze was $5 \mathrm{~m} \mathrm{~s}^{-1}$. After 09:00, the wind increased and turned clockwise. From 17:00 to 24:00, the wind was toward the northeast at the Chapala climatic station, whereas the wind direction was toward the northwest at the Alacranes Island and Tizapán climatic stations. The wind speed reached $7 \mathrm{~ms}^{-1}$.
Thus, the spatial orientation of the synoptic pulsation of the wind in Lake Chapala is due largely to the topography. The mountain chain that bounds the lake from north to south directs the synoptic air flows in a west-east direction.

\section{Temperature}

The temperature profiles from the water column that are shown in Fig. 3 were recorded from 12:00 to 14:30 from a north-south direction (shown in Fig. 1). For this time period,

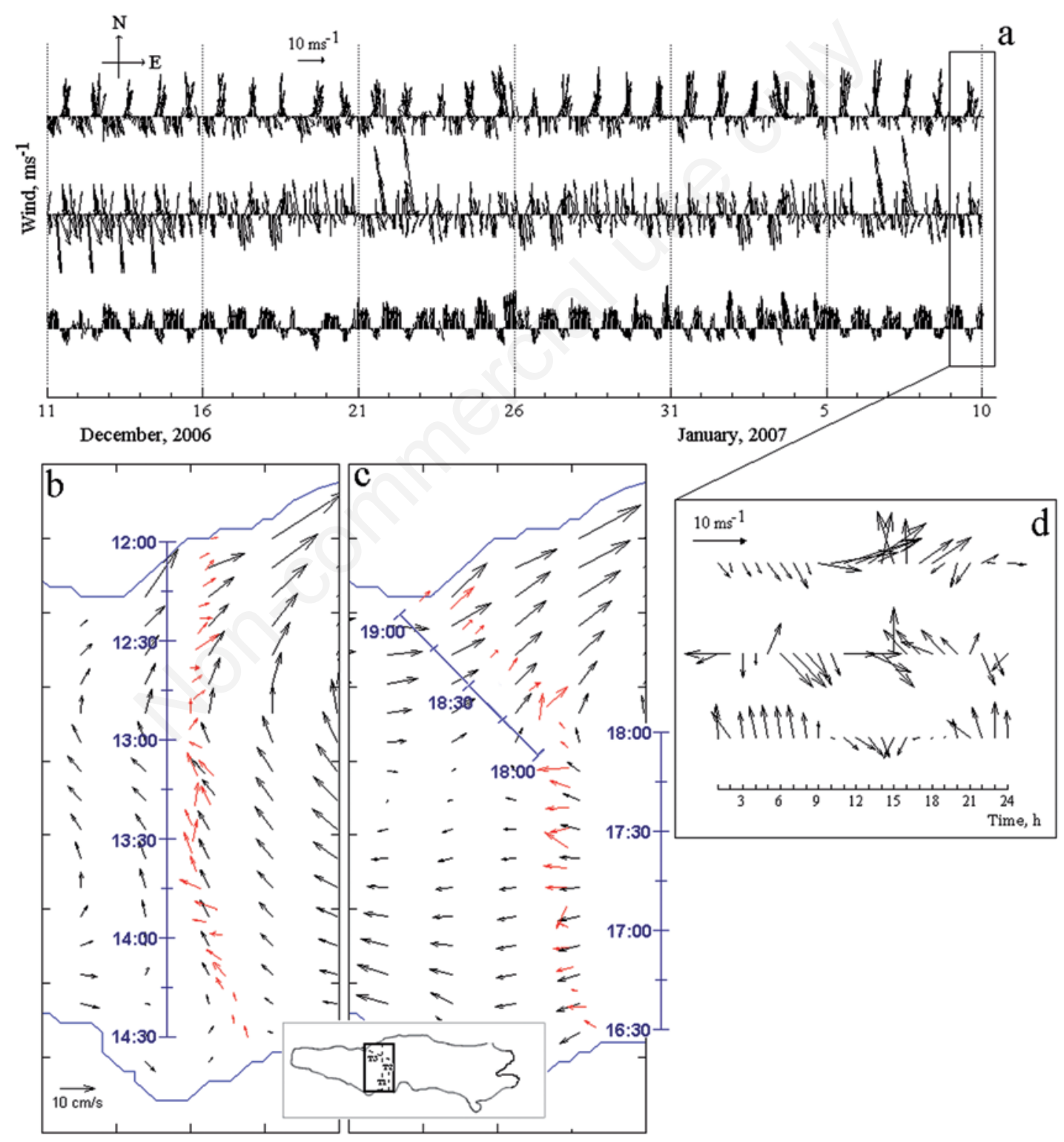

Fig. 2. a) Time series of wind fluctuations (registered by the weather stations in Chapala, Isla Alacranes and Tizapan). b) Modeled currents (black vectors) versus observed (red vectors) in the sampling area for transect T1, and (c) for the transect T2 and T3. d) The lower panel shows the daily course of average wind to 10 January 2007. 
the meteorological conditions in the lake were: an average air temperature of $14.5^{\circ} \mathrm{C}$ and winds of $12 \mathrm{~ms}^{-1}$ directed to the coast, as recorded by a weather station in the town of Chapala. Fig. 3 shows that the temperature oscillates between 17 and $18.5^{\circ} \mathrm{C}$ in the transect $\mathrm{T} 1$ and that the thermocline deepens in only a few hours (Fig. 3a). It is also shown that the north part is $1^{\circ} \mathrm{C}$ warmer than the south part (Fig. 3b).

Fig. 4 a,b shows the temperature transects T2 and T3, which were conducted at 16:40 to $18: 45$, two hours after the transect T1. The meteorological conditions recorded during the transect period were an average air temperature of $20.9^{\circ} \mathrm{C}$ and wind heading toward the lake, which is a typical breeze condition in Lake Chapala according to Filonov (2002). In these transects, heat penetration was observed toward the lower layer of the water column, showing a vertical gradient of $2.5^{\circ} \mathrm{C}$ in the first meter of water in relation to the lake's bottom (Fig. 4). Meanwhile, the transect temperatures for T2 and T3 varied between 17 and $20^{\circ} \mathrm{C}$ throughout their courses. For the last part of the sampling, the water column near the coast started to blend due to the effect of the lake's breeze. Furthermore, the north part of the transect T1 was warmer than the south part by $1^{\circ} \mathrm{C}$ (Fig. 4 c,d).

\section{Currents}

A simulation was generated from the HAMSOM model for a period of 30 days during the dry season, using

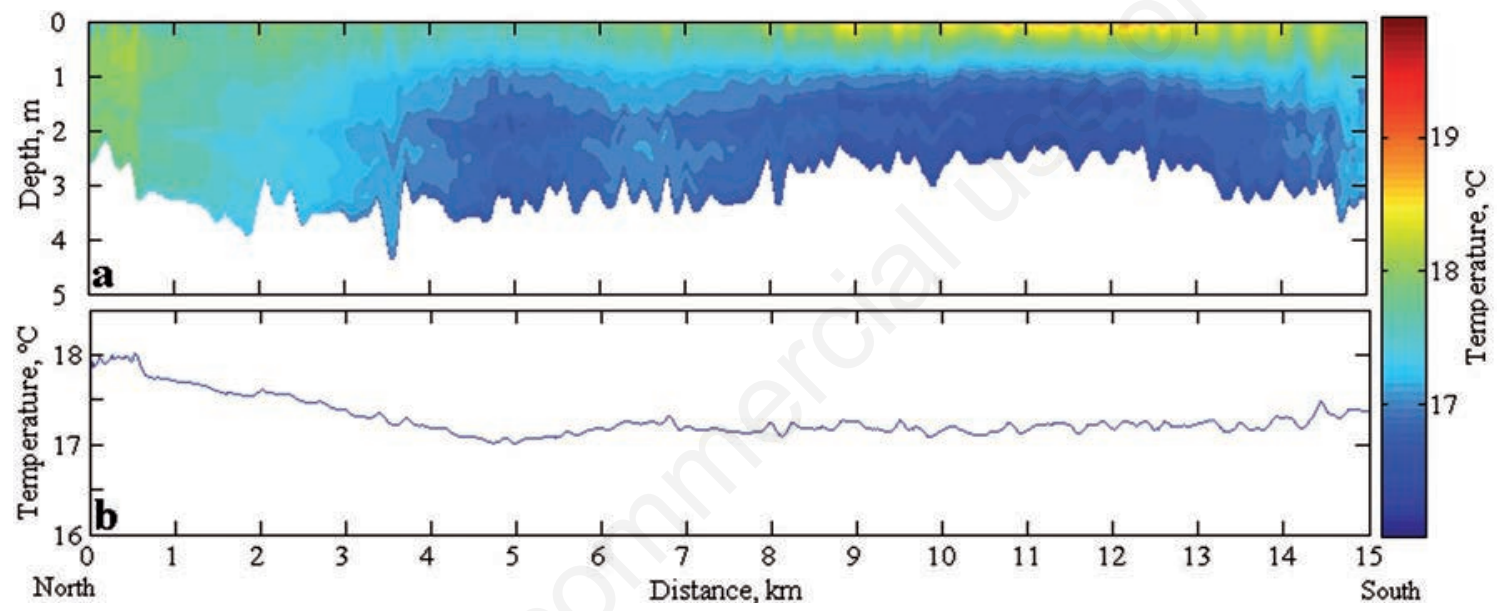

Fig. 3. a) Temperature distribution. b) Spatial average temperature from the transect $\mathrm{T} 1$ with a north-south direction, registered by the sensor chains on the 10 January 2007, in Lake Chapala.

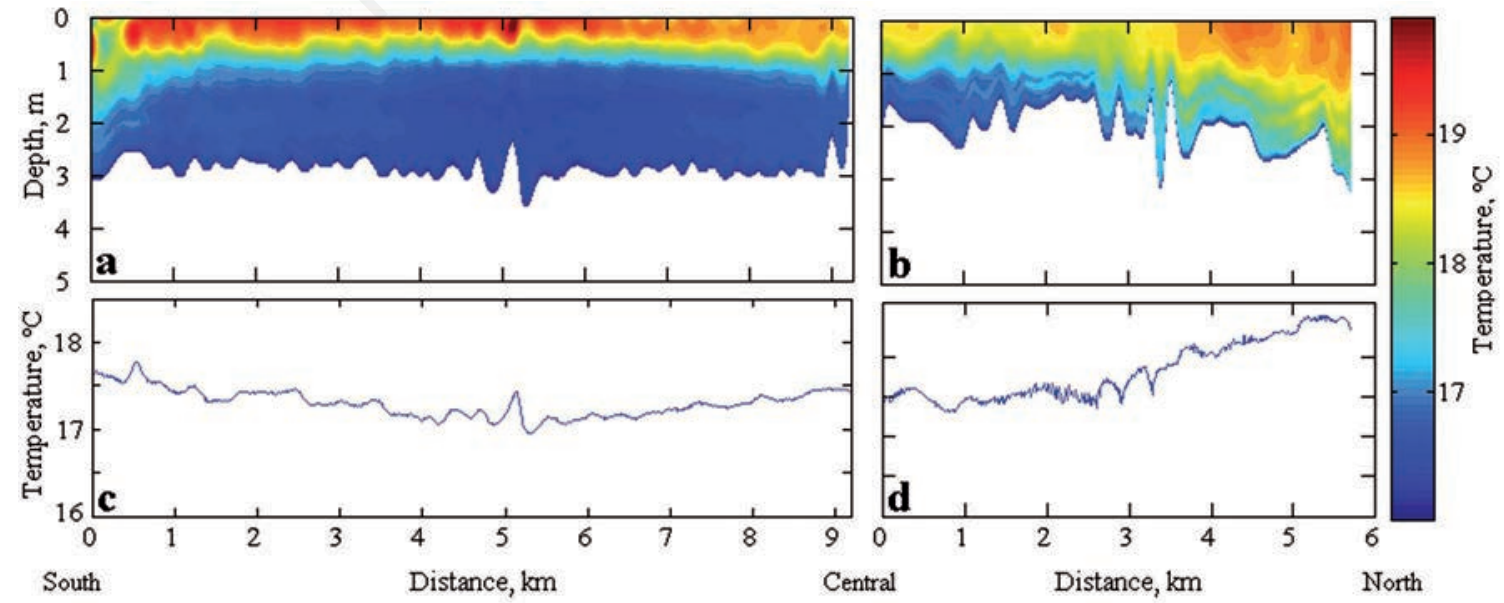

Fig. 4. a) Temperature distribution from transect T2, and (b) transect T3. c) Spatial average temperature from transect T2 with a southnorth direction, and (d) transect T3 with a northeast direction; recorded by the sensor chain on the 10 January 2007, on Lake Chapala. 
the wind field from the network of the weather stations in Chapala Lake (Fig. 1a). The inflow and outflow of rivers do not contribute to the lake in the dry season because during the dry season (May), the flow decreases by water retention in dams and presents a hydrological imbalance by over-exploitation in the lake (Güitrón, 2005). As a result, the input and output flows of the lake are insignificant. Information about the input-output flow of the rivers came from the CONAGUA (Mexico's National Water Council). The average flows through the Lerma and Santiago Rivers for the dry season are $600 \mathrm{~m}^{3} \mathrm{~s}^{-1}$ and $120 \mathrm{~m}^{3}$ $\mathrm{s}^{-1}$, respectively.

The model results in the last $24 \mathrm{~h}$ of simulation (from 10 January 2007) show very complex dynamics (Fig. 5). The features of the circulation patterns in the lake that are driven by the breeze are reflected by the presence of two gyres: one gyre is counter-clockwise (cyclonic), and the other is clockwise (anticyclonic), and they are located in the east-central and west-central part of the lake, respectively. Nevertheless, other gyres were observed near the east and west coastlines.

Fig. 5 shows the 3-hourly model results of the daily cycles of currents. The vortex of the anticyclonic gyre that was generated in the west side of the lake continues its development toward the northwest, remaining there during most of the simulation cycle. However, the cyclonic gyre that is located in the west-central part of the lake moves toward the southwest part and subsequently vanishes because of the bottom friction effect to integrate with the returning flow of the anticyclonic gyre that was previously mentioned. The simulations showed maximum currents near the south and north coast that reached $12 \mathrm{~cm}^{-1}$.

\section{Comparison of model with observations}

The wind forcing is considered to be the main mechanism that sustains the circulation (gyres) observed in Lake Chapala. The results of the measurements show vertically integrated current velocity recorded by the ADCP and the simulations for the sampling zone (Fig. 2 b,c).

The transect T1 was done from 12:00-14:30 in the north-south direction. The registered current reached 10 $\mathrm{cm} \mathrm{s}^{-1}$, with a northeast direction generated by the dominant wind from Lake Chapala (named as The Mexicano by the river men; Avalos, 2003). The results from the 13:00 $\mathrm{h}$ model are similar to the results of the sampling from the north zone of the lake (Fig. 2a), whereas the south zone shows a significant difference in the flow sample direction. Nevertheless, the samples from transects T2 and $\mathrm{T} 3$ recorded from $16: 30$ to $18: 00 \mathrm{~h}$ were similar to the simulation results from 18:00 $\mathrm{h}$ in the southern zone, with velocities that reached $15 \mathrm{~cm} \mathrm{~s}^{-1}$ (Fig. 2b). In the south part of the lake, the currents changed direction from west to south in just two hours.

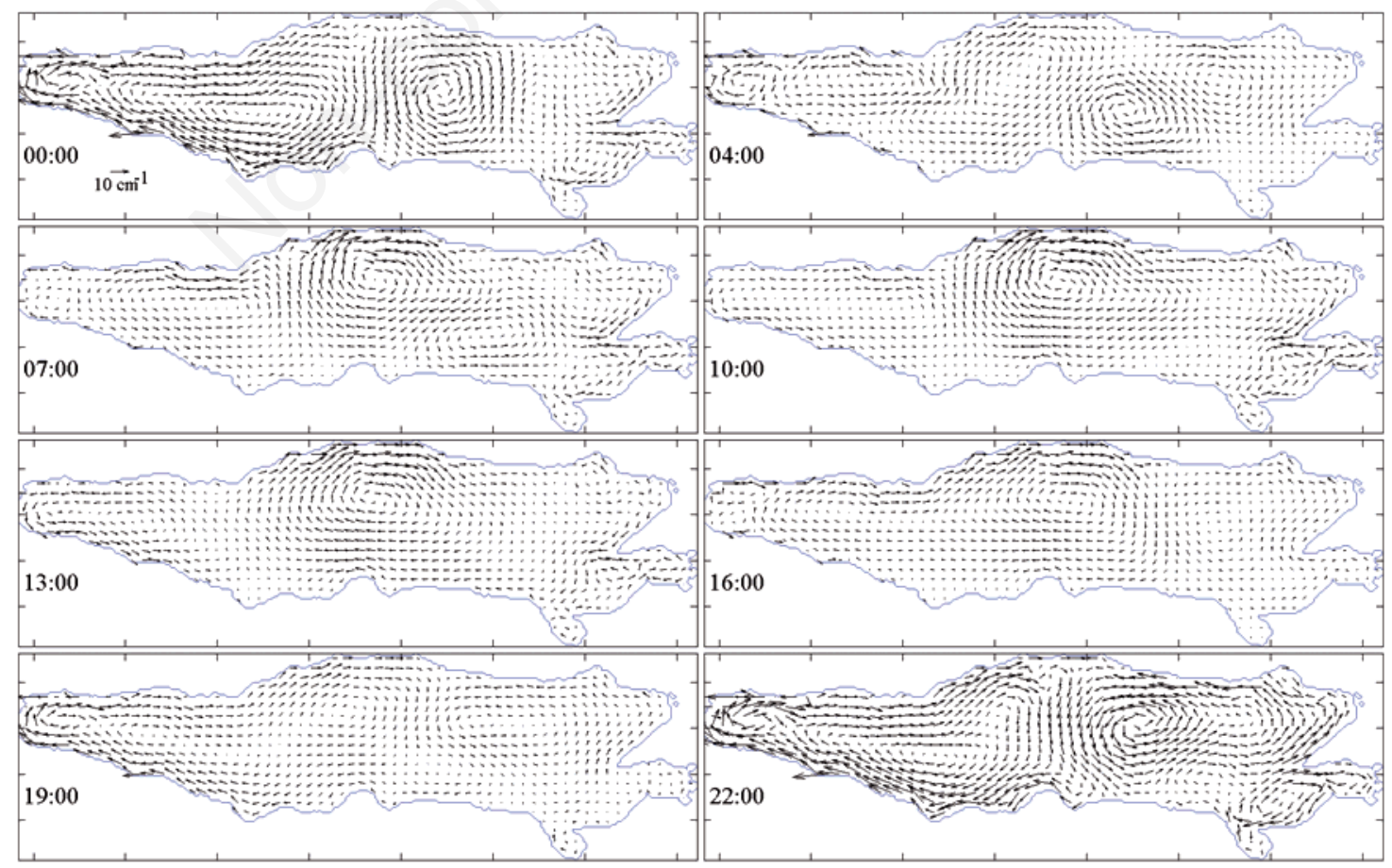

Fig. 5. Modeling of the currents induced by the wind fields in Lake Chapala during the dry season. 
Winds of $12 \mathrm{~ms}^{-1}$ were observed at a weather station situated in the Lake Chapala location at the same time as the measurements of transect T1, with a southeast direction. Only two hours after measurements of transects T2 and $\mathrm{T} 3$, the wind in the weather station changed direction toward the southeast with a velocity of $10 \mathrm{~ms}^{-1}$. The results were recorded in the model simulation records, which suggest that the effect of the morning breeze circulation adjusts to the model. Overall, there appears to be reasonably good agreement between the model predictions and the observations (Fig. 2 b,c).

\section{DISCUSSION AND CONCLUSIONS}

It is clear that the temperature samplings conducted in the lake prove that there is a complex thermodynamic regimen and a marked vertical stratification. The transect $\mathrm{T} 1$ showed a deepening thermocline. At the time when transects T2 and T3 are measured, the water rapidly heats up developing a sharp thermocline gradient of $2.5^{\circ} \mathrm{C}$ in the first meter. However, the stratification of the water column is destroyed by the effect of the current, which is generated by the breeze at the end of the transect T2; similar results are reported by Filonov and Tereshchenko (1999a, 1999b).

The three transects showed that the northern part of the lake is, on average, $1^{\circ} \mathrm{C}$ warmer than the southern part, in agreement with the study done by Tereshchenko et al. (2002) using satellite images.

The simulation results from the HAMSOM model reveal well-defined patterns with velocities that reach 12 $\mathrm{cms}^{-1}$; the most intense ones are near the coast. The two general circulation patterns along the lake were clearly identified. One anticyclonic gyre predominates in all simulation times, moving toward the east of the lake. The other gyre is cyclonic and moves toward the southeast of the lake to eventually generate a returning flow that will release in the direction of another circulation mode near the south coast.

Filonov and Tereshchenko (1999a) and Avalos (2003) reported the existence of a predominant circulation in the lake. However, the circulation was shown in a very vague manner due to the simplicity of the models that were used and to the data accessibility. The HAMSOM model that we used is a better approach for examining the temporal space in the circulation patterns in the lake in its dry season.

There appears to be quite good agreement between the current measurements and the model results. Obviously, the spatial coverage from the sampling that was done in January 2007 was not sufficient to identify the gyres generated from the model. Although Filonov (2002), Filonov et al., (1998) and Tereshchenko et al., (2002) described the circulation of the breeze on the lake, their results seem to be fairly limited because they only analyzed data from a weather station and their data collected were short time series and monthly averages. In addition, the difficulty of sampling in the lake is due to the many fishing nets and excess tourist traffic. However, good planning allowed us to carry out the experiment that was presented, in which we successfully integrated the data sets from a network of seven weather stations and measurements of temperature and currents in the lake. Therefore, our study is an important update that proves that the circulation in Lake Chapala changes significantly during the day due to the lake's breeze effect. This research finding is potentially important to understand the transportation of particles and contaminants in Lake Chapala.

\section{ACKNOWLEDGMENTS}

The authors would like to thank "Consejo Nacional de Ciencia y Tecnologia" (Mexico) for their economic support in the frame of the Project No. 33667-T.

\section{REFERENCES}

Avalos D, 2003. [Circulación de la Brisa y su influencia a la Estructura Térmica del Lago de Chapala, México].[Thesis in Spanish]. Universidad de Guadalajara, Jalisco.

Carbajal N, 1993. Modeling of the Circulation in the Gulf of California. PhD Thesis. University Hamburg, Germany.

De-Anda J, 2004. Solids distribution in Lake Chapala, México. J. Am. Water Resour. Assoc. 40:97-109.

Filonov AE, Tereshchenko I, 1997. Preliminary results of Lake Chapala, México. Eos T. Am. Geophys. Un. (Supplement) 78:46.

Filonov AE, Tereshchenko I, 1999a. Thermal fronts and Internal nonliner waves in shallow tropical Lake Chapala, Mexico. Russ. Meteorol. Hydrol. 1:58-64.

Filonov AE, Tereshchenko I, 1999b. Thermal lenses and internal solitones in the shallow lake Chapala, Mexico. Chin. J. Oceanol. Limn. 17:308-314.

Filonov AE, Tereshchenko I, Monzón C, 1998. Oscillations of the hydrometeorological characteristics in the region of Lake Chapala for intervals of days to decades. Geof. Inter. 37:393-308.

Filonov AE, 2002. On the dynamical response of Lake Chapala, Mexico to lake breeze forcing. Hydrobiologia 467:141-157.

Ganf GG, Viner AB, 1973. Ecological stability in a shallow equatorial lake (Lake George, Uganda). P. Roy. Soc. Lond. B Bio. 184:321-346.

Güitrón A, 2005. [Modelación matemática en la construcción de consensos para la gestión integrada del agua en la cuenca Lerma Chapala]. In: S. Vargas and E. Mollard (eds.), [Los retos del agua en la cuenca LermaChapala. Aportes para su estudio y discussion].[Book in Spanish]. IRD-IMTA, Morelos.

Hainbucher D, Pohlmann T, Backhaus J, 1987. Transport of conservative passive tracer in the North Sea: first results of a circulation and transport model. Cont. Shelf Res. 7:1161-1179.

Hansen AM, 1994. [Migración de la Contaminación].[Article in Spanish]. Gaceta del Lerma Especial 77-93.

Hare L, Carter JC, 1984. Diel and seasonal physico-chemical fluctuations in a small natural West African lake. Freshwater Biol. 14:597-610.

Ilyina T, Pohlmann T, Lammel G, Sündermann J, 2006. A fate and 
transport ocean model for persistent organic pollutants and its application to the North Sea. J. Marine Syst. 63:1-19.

Ishikawa T, Tanaka M, 1993. Diurnal stratification and its effects on wind-induced currents and water qualities in Lake Kasumigaura, Japan. J. Hydraul. Res. 31:307-322.

Jain MK, 2003. Numerical methods for scientific and engineering computation. New Age International, New Delhi: 844 pp.

Jáuregui E, 1995. Rainfall fluctuations and tropical storm activity in Mexico. Erdkunde 49:39-48.

Marinone SG, 2003. A three-dimensional model of the mean and seasonal circulation of the Gulf of California. J. Geophys. Res-Oc. Atm. 108:C103325.

Mosiño PA, Garcia E, 1974. The climate of Mexico, p. 345-504. In: R.A. Bryson and F.K. Hare (eds.), The climates of North
America. Word survey of climatology Elsevier Sci., New York.

Riehl H, 1979. Climate and weather of the tropics. Academic Press, London: $611 \mathrm{pp}$.

Serrano D, Filonov AE, Tereshchenko I, 2002. Dynamic response to valley breeze circulation in Santa Maria del Oro, a volcanic lake in Mexico. Geophys. Res. Lett. 29:27-31.

Tereshchenko I, Filonov AE, Gallegos A, Monzón C, Rodríguez R, 2002. El Niño 1997-98 and the hydrometeorological variability of Chapala, a shallow tropical lake in Mexico. J. Hydrol. 264:133-146.

Trump CL, Marmorino G, 1997. Calibration of a gyrocompass using ADCP and DGPS data. J. Atmos. Ocean Tech. 14:211-214.

Valle-Levinson A, Atkinson L, 1999. Spatial gradients in the flow over an estuarine channel. Estuar. Coast. 22:179-193. 